\title{
Low-pay sectors, earnings mobility and economic policy in the UK
}

\author{
Neil Lee ${ }^{1}$, Anne Green ${ }^{2} \&$ Paul Sissons ${ }^{3}$
}

\begin{abstract}
Low pay is a significant and growing issue in many developed economies. Sectoral approaches are often used in both economic development and labour market policy, yet there is little evidence on how low pay and earnings mobility vary by sector. This article investigates this issue in the UK. It shows pronounced sectoral variations in low pay and earnings mobility. It highlights the policy implications of growth in large, low paying sectors. While policymakers have focused on high-wage, high-skill sectors, efforts to improve productivity in low-wage sectors could improve living standards and the UK's economic performance.
\end{abstract}

Keywords: Precarait, Wage progression, Sectors, Industrial Policy

\footnotetext{
${ }^{1}$ Corresponding author: Department of Geography \& Environment, London School of Economics, Houghton Street, London WC2A 2E. n.d.lee@1se.ac.uk

${ }^{2}$ City-REDI (Regional Economic Development Institute), Birmingham Business School, University of Birmingham, Birmingham, B15 2TT a.e.green.1@bham.ac.uk

${ }^{3}$ Centre for Business in Society, Coventry University, Coventry, CV1 5FB. Paul.sissons@coventry.ac.uk
} 


\section{Introduction}

Policymakers in the UK have focused on the supply side of the labour market. In common with other countries, this 'work first' approach has aimed to incentivise work, but paid little attention to skills or wage progression once in employment (Bruttel and Sol, 2006). As policymakers have focused on raising the employment rate, economic change has altered lower levels of the labour market. Long-term processes of technological change and international trade have apparently led to processes of employment polarisation and the decline of some mid-wage jobs for relatively less well-educated workers (North et al., 2009; Goos and Manning, 2009; Holmes and Mayhew, 2010; Sissons, 2011). Institutional change and falling rates of trade union membership have also reduced the bargaining power of lowwage workers, while increased use of outsourcing has led to a sharper focus on the cost of many low-skilled jobs. More recently, the 2007/8 global financial crisis had a disproportionate impact on the low-skilled labour market, with higher-earners relatively shielded from its impact (Lee, 2014; McKnight, 2015).

Following the financial crisis, the UK experienced what was described as a 'jobs miracle' by then Prime-Minister David Cameron, as employment rates remained relatively high despite weak GDP growth (Cameron, 2015). During the recession and through the early 2010s, workers in the UK experienced historically large reductions in the real value of wages (Blanchflower, 2015) across the wage distribution (Machin, 2015). UK productivity also stagnated (ONS 2015). The policy focus remained on getting individuals into work, but offered relatively little help to support them into appropriate employment (Wright, 2016). Less is spent on Active Labour Market Policy (ALMP) in the UK than in comparable economies (Berry, 2015), and spending is focused largely on job entry, with less emphasis on the sustainability of outcomes or quality of employment (although there have been some modest shifts in this regard) (Sissons and Green, forthcoming). At the same time, vocational training was often of poor quality, with the result that some workers were entering the labour market without required skills (Wolf, 2011). Post-compulsory education moved from being funded by the state to being funded by individuals and employers (Foster, 2017).

The UK's strong employment performance in the period was accompanied by dire wage growth: of OECD countries, only Greece had worse real wage growth between 2008 and 2015 (Tilly, 2017). There are significant concerns about the nature and extent of low pay in many developed economies (Marx et al., 2012; Bennett, 2014; Linneker and Wills, 2016), and the UK has one of the highest rates of low pay in the OECD (Corlett and Whittaker, 2014). This is, in part, the result of these policy efforts, as the coalition government of 2010-2015 
saw low pay as a necessary evil if employment rates were to be kept high (McKnight, 2016). There are now significant concerns about the nature and extent of in-work poverty in the UK, with claims that a new "precariat" of low wage service workers in precarious occupations on non-permanent employment contracts has emerged (Lindsay and McQuaid, 2004; Standing, 2011, Rubery et al., 2016; Montgomery et al., 2017). Similar trends are apparent in a number of other countries with liberal welfare regimes, which have increased the value of minimum wages in an effort to partly redress the more deleterious effects of labour market deregulation (Wilson, 2017).

Patterns of low pay vary significantly by sector. Yet, the ongoing focus of UK economic development policy has been on advanced high-technology sectors (such as aerospace), with relatively less emphasis on low-productivity areas of the economy (see HM Government, 2017). The decline of employment in manufacturing, which traditionally offered relatively high wage jobs, has been accompanied by growth in relatively low wage employment in the service sector, including work in care and retail, with many of the long-term unemployment resistant to changing sectors. Concerns about sectoral change overlap with those about wage mobility and the ability of workers to escape low pay, and research has increasingly considered the potential for low wage workers to escape low pay (Bennett, 2014; Marx et al., 2012). In the UK, there is increased interest in the role of low-paid sectors in the UK's productivity problem, with low pay sectors responsible for around a third of the productivity gap between the UK and countries such as France or Germany (Thompson et al., 2016). Raising productivity in low-paid sectors might potentially both increase productivity and reduce low-pay (Joseph Rowntree Foundation, 2017).

However, there is relatively little academic evidence on sectoral variation in low pay and earnings mobility. This is an important omission for both policy and research. Low pay matters for research and policy related to poverty: in the UK in 2013 more than half of those in poverty were in working households (Joseph Rowntree Foundation, 2014), while pay rates are an important determinant of household poverty (Maitre et al., 2012). Moreover, in the context of relatively low unemployment in the UK it is also important to consider how upward earnings mobility from low pay can be achieved. For policymakers, sectors are important for targeting, both in terms of the sectors which economic development policy seeks to encourage and the way in which the government addresses productivity. For example, sectoral bodies have long been used in the UK as a way of improving and addressing sectoral skills needs (Leitch, 2006; Payne, 2007; Department for Business Innovation and Skills, 2014), although their role has been more peripheral than in some other countries (City and Guilds, 2011; Green et al., 2016). Unions are also regularly involved in 
wage-bargaining at a sectoral level. Some support for the unemployed has been delivered on a sectoral basis, with 'sector-based work academies' forming part of the UK Coalition government's agenda (McKnight, 2015; Ward et al., 2016). This has formed part of the 'work first' approach which has prioritized high volume, but often low-paid employment opportunities. The UK case has wider implications as it has a combination of a strong focus on supply side policies, relatively weak institutional coordination and little focus on the demand side of the labour market.

This article aims to develop a 'big picture' view of low pay in the UK's labour market with a focus on how this relates to sector. It does this through an analysis of two different datasets: (1) the Quarterly Labour Force Survey (QLFS), which offers a large sample size but only considers individuals for a snapshot in time, and (2) the Five-Quarter Longitudinal LFS (LLFS) which 'follows' individuals for five quarters and so allows short-term labour market transitions to be investigated. It investigates three central research questions:

(1) How do patterns of low pay vary by sector and to what extent are any sectoral variations related to worker characteristics, rather than sectoral variation independently?

(2) Do probabilities of leaving low pay vary sectorally, and are these related to worker characteristics?

(3) How do these sectoral variations relate to likely future trends in the profile of employment?

The article argues that the growth of some high-employment, low wage sectors in the UK economy is in part the result of government decisions in both labour market policy and economic development policy. The article's key finding is that there are pronounced 'sectoral effects' in low pay, which exist even when controlling for individual characteristics. This suggests that policy focused on sectors has a stronger role than is currently the case to play in shaping the wage distribution. In addressing both current and future projected sectoral dimensions of the labour market, this article makes a number of contributions to the literature, which has tended to focus on the decline of manufacturing and resulting unemployment (e.g. Beatty et al., 2009; North et al., 2009). It is the first article to focus on the links between sector of employment and low pay in a quantitative framework. In doing so, it helps to inform policy debates about how low pay should be addressed. It also uses a research methodology which includes controls for probabilities of employment, so addressing concerns about selection into low-paid employment, something largely unacknowledged in the literature to date. Moreover, this article is the first to show independent sector effects on low pay, independent of other personal characteristics. 
In addressing these issues, we begin by reviewing the literature on the nature of structural change in the economy, how low pay varies by sector and the implications for policymakers. In section three, we present descriptive statistics investigating the characteristics of low-paid employment and also short-term transitions out of low pay and how these vary by sector. Section four presents descriptive statistics, before section five sets out a regression model which considers the extent to which low pay patterns and transitions vary by sector, before relating patterns of low pay to projected future growth. Section six considers implications for policy.

\section{Sectoral change, low pay and employment}

\section{Economic change and the low-wage labour market}

There is widespread concern about the changing labour markets of many developed economies. There are many ways to explain this, but the dominant theoretical model has come from economics: the idea of employment polarization (Jones and Green, 2009; Holmes and Mayhew, 2010; Sissons, 2011). A set of related changes have occurred - technological change, the decline of labour market institutions, offshoring, and changes in product market demand - which have helped improve the productivity of certain occupations, while substituting for other jobs (Goos and Manning, 2009). The result has been employment polarization: growth in cognitive work at the top of the labour market; decline in mid-skilled, mid-paid employment which is either vulnerable to outsourcing (manufacturing) or can be automated (book-keeping); and growing employment towards the bottom, in jobs which are hard to automate (such as care work) in service industries which suffer from low productivity growth.

A related explanation for sectoral change comes from Baumol's (1967) work on unbalanced growth. He argues that there are two types of economic activity: (1) "technologically progressive activities in which innovations, capital accumulation, and economies of large scale all make for a cumulative rise in output per capita" and (2) those which "by their very nature permit only sporadic increases in productivity" (1967: 415-416). Type 1 includes industries like Manufacturing, in which innovation increases productivity and enables output to increase as employment falls. Type 2 includes service activities such as teaching, where increasing efficiency (e.g. by increasing class sizes) is not always seen as positive. In this way, productivity improvements in some sectors may then lead to labour being reallocated 
into those in which it is least productive, in a purely financial sense. This literature leads to the concern that there would be growth in the number of low wage jobs. It also suggests that the shrinking middle of the labour market might reduce earnings progression, by providing fewer mid-level 'stepping stone' jobs.

Sectors, economic development and labour market policy

The concepts suggested are helpful in explaining low pay, but policy also plays a significant role. There are longstanding concerns about the UK growth model and its relationship to employment quality. The labour market is lightly regulated, which some argue has increased employment insecurity (Davies and Freedland, 2007). Unionisation is associated with a lower rate of low-paid work but has almost halved since the late 1970s (Grimshaw, 2011; Department for Business Innovation and Skills, 2015). Influential studies have suggested a low-skills equilibrium and weak institutions may have constrained firms' movement to higher skill/higher pay operating models (Finegold and Soskice, 1988; Wilson and Hogarth, 2003). Estevez-Abe et al. (2001) argue the relative abundance of particular skills will influence firms' strategies. With limited employment protection and low replacement benefits, workers have few incentives to develop specific skills. Moreover, there are well recognized failures in the vocational education system (Wolf, 2011). The result is a relative abundance of low-level skills, with few incentives for employers to develop high-road product strategies. There is also evidence of high rates of skills under-utilisation, demonstrating the importance of employer practices and demand-side issues (Keep, 2016).

Successive UK governments have believed that labour market activation, and increasing employment rates, would help address the problem of high levels of low pay. Active labour market policy is seen as an important way of addressing poverty, a policy assumption increasingly prevalent across Europe (Scott, 2006). There is some evidence on this point. Jenkins (2013) shows that the majority of exits from poverty are associated with entry into employment. Similarly, it is hard to see families leaving poverty without some form of sustained employment. However, there is a growing realization that entry into employment is, while necessary in most cases, not a sufficient condition for leaving poverty (Lewis, 2011; Shildrick et al., 2014)).

Sectoral approaches are also widely used in economic development policy. The UK has a laissez-faire economic model, with little economic coordination and only limited attempts to shape its sectoral structure (Hall and Soskice, 2001). The result is a sectoral employment pattern dominated by market processes, rather than conscious policy efforts. Under the 
coalition, UK policymakers attempted to 'rebalance' the economy away from Finance and towards other sectors, notably Manufacturing. However, progress towards this goal was questioned, as were the efforts the British government put in place to try and achieve them (Berry and Hay, 2016). Instead, there remained an overarching focus on high-end sectors in economic development, such as Finance and High-technology, with little effort to shape the economy at the lower end.

\section{Evidence gaps and research questions}

Few studies have considered the sectoral patterns of low pay. An important question is how low pay varies by sector, and whether this is due to the composition of the workforce or some 'sectoral' factor. In an early UK study, Bosanquet and Stephens (1972) investigate patterns of low pay and conclude that it is mainly found in Services, with Manufacturing paying better. Most studies have focused simply on worker characteristics, such as education, ethnicity or age. But it is important to know whether there is an independent 'sector effect' on low pay, beyond individual worker characteristics. Yet, despite widespread interest in low pay, there is little evidence on this point.

A second, related question is sectors role in influencing earnings mobility out of low pay. Kemp et al. (2004: 45) argue that the type of employment is as crucial in potentially acting as "stepping stones" to new, better paid employment. Considering Scotland, Scott (2006: 680) argues that: "There remains a continuing need to build ladders up out of the marginal jobs most likely to be available to low qualified workless people, not least in the significant public sector where many of the most disadvantaged are most likely to find their first jobs." Some sectors provide employment for a short time who then find better paid employment elsewhere, such as students who later move to graduate jobs. Alternatively, mobility may be within-sector, as workers progress in work. Using long-term earnings data, Hurrell (2013) investigates the extent to which industries matter for upwards earning mobility. He finds that Manufacturing workers, Wholesale and Retail workers and Accommodation and Food Service workers have lower probabilities of escaping low pay. Hurrell's results are helpful as they consider a long-time period, but they do not control for initial likelihood of becoming low paid.

A final question has also been unexplored: what do future patterns of sectoral employment growth imply for low pay? Given the projections of some economic models, that there will be growth at the top and bottom in the labour market, it is important to consider medium-term projections of employment structure and what these mean for low pay. For example, if 
Baumol's view that cost disease will lead to large increases in employment in low productivity sectors is correct, this will have implications for future patterns of low pay and so policy in this area.

\section{Data and Methodology}

\section{The Labour Force Survey}

To investigate sectoral variation in low-pay this article uses two related datasets for the period 2010-2014. First, we use the Quarterly Labour Force Survey (QLFS) to give a 'big picture' overview of sectoral variation in low pay. This dataset gives the largest available sample size and so provides the most accurate overview. However, it gives no information on whether individuals remain stuck in low pay or leave rapidly. To address this limitation, we also use the 5 Quarter Longitudinal Labour Force Survey (LLFS). This is a reduced version of the QLFS with each worker interviewed for five successive quarters. However, the sample is significantly reduced, as is the number of questions asked. ${ }^{4}$

\section{Defining low pay}

There is no independent measure of 'in-work poverty' in the LFS. Instead, we document low pay in the labour market using the common definition of "hourly wages below two-thirds of gross median hourly pay for all employees" (Gardiner and Millar, 2006; Solow, 2008; Corlett and Gardiner, 2015). We estimate this according to wages in 2015 data as follows:

1. Low pay: hourly wages of less than $2 / 3^{\text {rd }} \mathrm{s}$ of gross median hourly pay for all employees. Indexed to 2015 money this is $£ 7.43$.

We also consider an additional variable calculated using the LLFS:

2. Upward earning mobility: Whether an individual in low pay in $\mathrm{Q} 1$ is no longer in low pay by Q5 (while remaining in employment).

\footnotetext{
${ }^{4}$ For both datasets we have undertaken some limited data cleaning. Duplicate observations have been removed and, as recommended by the UK Data Archive, weights with negative values have been dropped. The sample has been restricted to those of working age (for consistency throughout the time period, this has been defined as 16-64 for males and 16-59 for women). This gives around 250,000 observations for the LFS, of which around 130,000 are in employment, and over 60,000 for the LLFS.
} 
The sectors we use are adapted from the 2007 Standard Industrial Classification (SIC) codes. Because of the importance of care work in low pay in the UK we split health sector into its three components (Human Health, Residential Care, Social Work). ${ }^{5}$ This gives a final set of 21 sectors: (1) Agriculture, Forestry and Fishing, (2) Mining, (3) Manufacturing, (4) Electricity, (5) Water supply, (6) Construction, (7) Wholesale and Retail Trade, (8) Transportation and Storage, (9) Accommodation and Food Services, (10) Information and Communications, (11) Financial and Insurance Activities, (12) Real Estate Activities, (13) Professional, Scientific and Technical, (14) Admin and Support, (15) Public Administration and Defence, (16) Education, (17) Arts, Entertainment and Recreation, (18) Other services, (19) Human Health, (20) Residential Care, (21) Social work.

\section{Descriptive results}

We begin with descriptive results. According to the estimates in Table 1 around $21 \%$ of the workforce is in low pay, with little yearly variation except a small up-tick in 2014. However, there are significant sectoral differences. Table 2 gives basic descriptive statistics. There are high rates of low pay in Accommodation and Food Services, where almost $60 \%$ of the workforce fall into this category, significantly above the next highest sectors, Residential Care (40\%) and Wholesale and Retail (39\%). There are relatively high rates in Agriculture, Forestry and Fishing (35\%), Other Service Activities (34\%), Arts, Entertainment and Recreation (30\%) and Administration and Support (30\%).

\section{Table 1 here}

Table 2 here

These figures may distort our view of the low paid as very small sectors may have high shares of low paid workers. To give a view of the composition of the low paid workforce, Table 3 shows the proportion of all low paid working in each sector. Over a quarter of the low paid are in the Wholesale and Retail Sector (27\%), with 16\% in Accommodation and Food Services, followed by Education (9\%), Manufacturing (8\%) and Residential Care (6\%). Overall, these sectors account for $46 \%$ of employment but $66 \%$ of low paid employment.

Table 3 here

\footnotetext{
${ }^{5}$ The two very small sectors - Extra-territorial and Households as Employers, are merged into "Other Service Activities".
} 
The evidence presented above is static and does not consider progress over time. It is also useful to consider whether workers in particular sectors are more (or less) likely to experience pay rises and so escape poverty. Table 3 considers the share of workers in low pay in Q1 who are out of low pay in Q5 while remaining in employment. Columns 1 and 2 show moves regardless of changing sector. Low paid workers are most likely to leave low pay when working in Financial and Insurance Services (59\%), Information and Communications (46\%) and Public Administration (44\%). The lowest chances are in Other services (19\%), Agriculture, Forestry and Fishing (20\%), Wholesale and Retail (23\%), and Administration and Support (24\%).

\section{Figure 1 here}

Finally, we consider how these two indicators are related. Figure 1 shows the relationship between the share of workers in low pay and the share of workers in low pay in Q1 who leave it by Q5. As might be expected, the relationship is negative and statistically significant: the sectors with the highest share of low paid workers have the lowest chance of leaving it. Low pay in these sectors is likely to be sustained rather than a short-term issue.

\section{Regression models and results}

\section{Modelling probabilities of low pay}

It is useful to know the extent to which poverty is determined by the sector or the characteristics of the workforce. In the former case, policy may be best targeted at the sector itself, the firms within it or through sectoral bodies. In the latter case, it might be more important to focus on sector-neutral factors such as workforce skills. To investigate this, and see if there is some innate 'sector' effect, we run two forms of multiple regression models. We present marginal effects which show the percentage increase in probabilities resulting from working in different sectors.

The basic models are estimated as probit regressions (using a binary response variable). We use two dependent variables: (1) whether the individual is in low pay, and (2) if the individual has left low pay in Q5 if they were in low pay in Q1. We also control for a set of personal characteristics likely to impact on probability of low pay. First we include three variables for education: low (no formal qualifications, GCSE grades D-G, 'Other qualifications'), medium (A-Levels or higher, GCSE grades A-C, ONC/BTEC) with a reference category of high 
(Degree level or Higher Education). Better-educated workers are less likely to be in low pay, but we expect relatively less well qualified workers to be more likely to be in low pay.

We also control for relevant individual characteristics. As workers develop skills and experience with age, we include a simple variable for age. Yet because the benefits of pastexperience may diminish with time, we control for this with age squared. According to standard human capital theory, the coefficient on the former should be positive and the latter negative. Ethnicity and migration status may also matter. To account for possible labour market discrimination, we include a variable for non-white ethnicity. Migrants may be particularly likely to enter low wage work, so we also control for whether workers are UKborn. Clearly, gender will influence probabilities of low pay. There are longstanding concerns about both gender discrimination and the impact of motherhood on careers (Stewart, 2009; 2013). Because of this, we expect women to be more likely than men to be in low pay. We also control for disability which, because of discrimination in the labour market and restricted access to some jobs, we expect to increase probabilities of low pay (Beatty et al., 2009). Finally, we include a control for whether workers are part-time. We expect part-time workers to be particularly likely to experience low pay.

As the chances of being in low pay are conditional on entry into low pay in the first place, selection bias is a problem in these models. To address this issue, we estimate a Heckman selection model (technically, to correct for sample selection bias). This basically runs a regression for probability of being in low pay and then uses that to 'correct' the second stage regression for probability of escaping it. Doing so requires a variable which is positively related to labour market entry, but which has no relationship with probabilities of low pay employment. In this case, we use whether the individual is divorced which is negatively related to labour market entry but has no relationship with low pay. For the upwards earning mobility variable, disability status is associated with being in low pay, but does not seem to be statistically significantly related to future upward earning mobility.

\section{Results: Low pay by sector, controlling for worker characteristics}

Table 4 gives the results of the regressions. Columns $1-3$ consider the probabilities of low pay. Column 1 includes only year / quarter dummies to control for time-trends, they do not include other controls and are essentially a statistical significance test for the descriptive statistics, controlling for year-on-year variation. Column 2 includes controls for personal characteristics such as education, migration status, gender, ethnicity, disability and age (including these helps separate out an independent 'sector' effect from labour market impact 
of these personal characteristics). Column 3 gives the results of the Heckman selection model which controls both for personal characteristics and the selection into the labour market. Marginal effects are presented, giving percentage changes controlling for other factors.

\section{Table 4 here}

\section{Figure 3 here}

We first focus on the sectoral results where the reference category is Manufacturing, meaning sectoral results should be seen as relative to this sector. Without controls, the highest probability of low pay is in Accommodation and Food Services - an individual in this sector is $45 \%$ more likely to be in low pay than in Manufacturing. However, once controlling for personal characteristics this figure almost halves, before falling once more once after controlling for selection into employment. The other large positive effects are in Wholesale and Retail, Residential Care and Agriculture, Forestry and Fishing. Importantly, these are relatively persistent effects however the model is specified. Overall, this shows that sector of employment does seem to have a persistent effect on probabilities of low pay, even controlling for individual characteristics. For example, even controlling for their age, qualifications, migration status and disability, workers in Accommodation and Food are 17\% more likely to be in low pay than an observationally identical worker in Manufacturing.

Columns 4-6 consider the relationship between sector and chances of leaving low pay by Q5. In this case, the Heckman models are estimated on probabilities of being in low pay in Q1. First, we consider how chances of leaving low pay vary by sector. Relative to Education there are higher probabilities of being in this category in two sectors: Wholesale and Retail and, without controls, Accommodation and Food. This may be because of the higher probabilities of being in low pay in these sectors, so column 6 repeats these with selection into low pay considered. The results here suggest that, controlling for personal characteristics and selection into low pay, the sectors with higher probabilities than manufacturing of leaving low pay are Human Health, Finance and Insurance, and Public Administration and Defense. Overall, the picture is one where sector also matters for upwards earnings mobility: low paid workers in these sectors have a higher chance of not being low paid a year later.

\section{Future growth in low pay occupations}

The final research question concerns the implications of sectoral change for patterns of low pay in the future. To investigate this question, we relate the descriptive statistics set out in section 4 to the most recent 'Working Futures' employment projections for the UK economy 
between 2014 and 2024 (Wilson et al, 2016). Projections are given by sector and occupation over the next ten-year period and are based on both past trends and macroeconomic forecasts.

\section{Figure 4 here}

Figure 4 plots projected absolute employment growth by sector for 2014-2024 against the sectoral share of low paid workers in 2011-4. This relies on the strong assumption that the occupational composition of these sectors does not change, as an exercise to focus solely on sectoral change. The first point of note is that there is no overall correlation between low pay and projected employment growth by sector - suggesting that structural change is not closely associated with a clear trend for increasing or decreasing low pay. Only a few low-paid sectors - notably Agriculture, Forestry and Fishing - are likely to decline significantly in size over the medium term. But other trends may exacerbate changes in low pay. In particular, Manufacturing, a relatively larger sector and one which provides reasonably well-paid work for those without degrees, is projected to shrink significantly. Much of this will be accommodated by replacement demand, but this will change the structure of the labour market.

However, it is still useful to see the sectors likely to experience the largest increase in the number of low-paid workers. The sectors with high employment growth and low pay are those which are the highest priority to address these challenges. Accommodation and food services is expected to experience significant growth which means that, if the rate of low pay remains the same, there will be an additional 190,000 low paid workers in the sector, with Wholesale and retail adding a further 131,000. If all three Health and Social Care sub-sectors were combined, they would also create an additional 47,000 new low paid jobs. Overall, these suggest substantial growth in the low-paid economy, with a small number of sectors producing the lion's share of new low paid jobs. Past research, however, has suggested that many of the long-term unemployed can be resistant to taking employment in these expanding sectors of the economy.

\section{Conclusions and implications for policy}

Since the 2007/8 crisis, the UK has experienced relatively high rates of employment, but at the cost of low real wage growth. Low pay has become a significant problem. Most of the key policy agendas have focused on the supply-side, with the result that many workers found employment in sectors with high rates of low pay. This article has focused on the importance 
of sectoral variation in low pay, both in understanding the characteristics of low pay in the UK and the policy measures which might deal with this. It documents a number of new empirical findings. First, we find pronounced sectoral variation in the extent of low pay. For example, workers in Accommodation and Food Services are 25\% more likely to be in low pay than workers in Manufacturing, when controlling for age, gender, qualifications, ethnicity, disability and migration status. This suggests that there is a 'sector effect' independent from the personal characteristics of workers in the sector. For policymakers, focusing interventions - for example, skills upgrading - in these sectors might be a useful way to target low pay. In particular, there have been significant efforts to expand coverage of a voluntary living wage across the UK (Wills and Linneker, 2014; Linneker and Wills, 2016). Our results suggest sectors where efforts could be best focused.

A challenge of these low pay sectors is if workers are unable to increase their earnings. This article's second research question investigated sectoral patterns of upward earnings mobility. There is also pronounced sectoral variation in short-term movements out of low pay. Many of the sectors with high probabilities of upward earnings mobility, for example Human Health and Education, are dominated by the public sector. If policy is focused on improving living standards for those already in work, some form of targeting by sectors matters. While the UK welfare-to-work programmes of the early 2000s were focused on job entry (Taylor and Rees, 2016), there has recently been greater focus on outcomes of job sustainability and progression. The challenge here is that while providers have often focused on placing claimants into employment in low-wage service jobs, these are in sectors with little upward mobility. Growth in low wage service employment in sectors with low upwards mobility may make it hard to reconcile the targets of activation and progression. Moreover, other policy agendas - such as the introduction of fees for employment tribunals - have made it harder for workers to lobby for better conditions. New approaches to job design and training will be needed here (Sissons et al., 2017).

Finally, the article has considered future growth in low paid employment. According to patterns of projected employment growth by sector there is likely to be significant growth in Accommodation and Food Services, Wholesale and Retail, and Admin and Support. Addressing high rates of low pay in these sectors is a potentially important target for government policy to address challenges of low pay in future.

These results are rooted in the UK's dominant policy model, which has focused on supplyside labour market interventions with little effort to shape the sectoral composition of the economy. The result has been relatively high levels of low pay, driven by high employment in 
low wage sectors. One way of dealing with this has been the use of a wage floor, with a minimum wage of some form. These influence the low paid sectors disproportionately (Thompson et al., 2016). The question is whether they will respond by increasing productivity or further reducing working conditions for low wage workers. Evidence from past minimum wage analyses suggests that in the UK they have tended to increase productivity in low wage sectors (Riley and Rosazza Bondibene, 2017), although these depend crucially on the level at which the minimum wage is set. Other aspects of labour market policy areas also matter, one area which has been underexplored in UK labour market policy is the idea that improving progression may help in reducing low pay. There are some signs that policymakers may be beginning to address these challenges, with new ideas emerging in how progression can be improved in low wage sectors (Sissons et al. 2016).

However, low pay is not simply a result of labour market policy. Outcomes in the labour market are the result of both policy frameworks (in labour market and other domains) and business activity. Since the 2007/8 financial crisis, UK policymakers have drawn on the idea of 'rebalancing' the economy away from crisis-prone financial services to manufacturing (Hay, 2013). As the evidence above shows, Manufacturing tends to have relatively low probabilities of low pay, even when controlling for workforce characteristics (although low paid manufacturing workers have relatively low upwards wage mobility, and there will be division within manufacturing). A policy shift to aid manufacturing may help reduce low pay. Yet, as Hay (2013) notes, manufacturing is unlikely to become a major employer in the medium term. Industrial policy to rebalance the economy has some role to play in addressing low pay, but it is unrealistic to expect major sectoral shifts, and even if this did happen the impact on low pay would be modest.

Two areas may prove more fruitful for policymakers. In the framework Estevez-Abe et al. (2001) develop, businesses respond to the supply of skills. The UK's low pay problem in sectors such as retail may reflect abundant supplies of workers with low level qualifications and business models that take advantage of them. Any efforts must focus on the quality of training, rather than simply the quantity. Policy development has been in this direction, but it will take time to see if improvements have any results. Secondly, changes in the system of vocational education in the UK would address this problem. However, post-Brexit changes in business models are perhaps more likely to be achieved through reduced labour supply as migrants no longer come to the UK. However, there is a strong rationale for policymakers to intervene to change business models, although this is hard to do. Within retail, for example, some companies have managed to follow strategies based on higher-wages (Ton, 2014), while others have focused on a low-skill, high turnover route (Devins et al., 2014). 
Overall, these results suggest an important tension for public policy: labour intensive, lowproductivity sectors provide employment, but at the cost of low labour productivity and pay. The challenge for policymakers is to reduce the extent of low pay, but to ensure the employment rate remains high. For example, automation and e-commerce may increase productivity in retail, but may reduce employment. It is unclear how to balance these two goals. However, there are some clear areas for policy. First, the public sector is a large employer and can show a lead in this area, while other sectors, such as care work, have an important element of state funding (at least for some beneficiaries). The example of social care is an instructive one. This is often projected to be a key future growth sector, and one in which the public sector plays a key role. Yet employment is often low paid and insecure, with a high prevalence of non-standard employment contracts (Montgomery et al., 2017).

These findings have some international implications. They show the limitations of a workfirst approach with little consideration of the demand-side. If workers end up stuck in low pay with little chance of upward wage mobility, this clearly has important implications for living standards and earnings. At the time of writing, the UK had an employment rate above the OECD average, but slightly below countries such as Germany or the Netherlands which have much better productivity performance. Better, more expensive active labour market policies as in the Dutch case, or better coordination as in Germany, are valuable parts of a labour market strategy (Hall and Soskice, 2001). Indeed, while elements of a 'work first' approach have been targeted in countries including the Netherlands and Germany, these countries all have significantly different institutions: stronger social partnerships, works councils and so on. These countries also tend to have more activist economic policy which balances the supply- and the demand-side of labour markets.

This article opens up new potential areas of research on low pay. While we consider the relationship between low pay and sector, this does not mean that individuals with low pay will necessarily be in poverty. Low pay does not always mean poverty, if individuals work in households where others work in better paid jobs. Future work may consider the extent to which sector influences poverty outcomes as well, potentially using household data. Second, while we consider short-term earnings mobility some of this is likely to be short-term movement around the low pay threshold. Other work may wish to consider longer-term views on earnings mobility, such as using the Understanding Society dataset. Third, we have not examined directly the issue of occupation, and future work may consider how this interacts with sectoral change. Finally, other countries have varying levels of low pay, and further comparative work would be useful. 


\section{Bibliography}

Baumol, W, 1967, Macroeconomics of Unbalanced Growth: The Anatomy of Urban Crisis. The American Economic Review 57, 3, 415-426

Beatty, C, Houston, D, Powell, R, and, Sissons P, 2009, A gendered theory of employment, unemployment and sickness, Environment and Planning C: Government and Policy, 27, 6, 958-974

Bennett, F, 2014, The living wage, low pay and in work poverty: Rethinking the relationships, Critical Social Policy, 34, 1, 46-65

Berry, C. 2015. The hyper-Anglicisation of active labour market policy: Facilitating and exemplifying a flawed growth model. SPERI Paper Number 4.

Berry, C. and Hay, C. 2016. The Great British 'Rebalancing' Act: The Construction and Implementation of an Economic Imperative for Exceptional Times. The British Journal of Politics and International Relations. 18 (1), 3-25.

Blanchflower, D. (2015) 'As good as it gets? The UK labour market in recession and recovery’ National Institute Economic Review. 231(Feb): F76-F80

Bosanquet, N, and Stephens, R, J, 1972, Another look at low pay, Journal of Social Policy, 1, 3, 245-257.

Bruttel, O. and Sol, E. 2006. Work first as a European model? Evidence from Germany and the Netherlands. Policy \& Politics, 34 (1), 69-89.

Cameron, D. 2015. Speech on the Jobs Miracle, Available from:

http://press.conservatives.com/post/116631921185/david-cameron-speech-on-the-jobsmiracle

City \& Guilds Centre for Skills Development, 2011, Sectoral approaches to skills, Series Briefing Note 7.

(http://www.skillsdevelopment.org/PDF/Sectoral\%20approaches\%20to\%20skills\%20updated \%202011\%20v1.0.pdf (accessed 21/5/16).

Corlett, A. and Whittaker, M. (2014) Low Pay Britain 2014, London: Resolution Foundation.

Corlett, A. and Gardiner, L. (2015) Low pay Britain 2015, London: Resolution Foundation.

Davies, P L. and Freedland, M. (2007) Towards a flexible labour market: labour legislation and regulation since the 1990s. Oxford: Oxford University Press.

Department for Business Innovation and Skills, 2014, Industrial Strategy: Government and Industry in Partnership, Progress Report.

https://www.gov.uk/government/uploads/system/uploads/attachment_data/file/306854/bis-14707-industrial-strategy-progress-report.pdf (accessed 21/5/16). 
Department for Business Innovation and Skills (2015) Trade Union membership 2015: Statistical Bulletin. London: BIS

Devins, D, Bickerstaffe, T, Mitchell, B, and Halliday, S, 2014 Improving progression in lowpaid, low-skilled retail, catering and care jobs. York, Joseph Rowntree Foundation.

Estevez-Abe, M., Iversen, T. and Soskice, D. (2001) Social Protection and the Formation of Skills: A Reinterpretation of the Welfare State. In Hall, P. and Soskice, D. (eds.) Varieties of Capitalism: The Institutional Foundations of Comparative Advantage. Oxford, Oxford University Press, 145-183.

Finegold, D. and Soskice, D. (1988) 'The failure of training in Britain'. Oxford Review of Economic Policy. 4(3), 21-53.

Foster, D. 2017. Adult further education funding in England since 2010. House of Commons Library Briefing Paper 7708.

Gardiner, K and Millar, J, 2006, How low-paid employees avoid poverty: An analysis by family type and household structure, Journal of Social Policy, 35, 351-369.

Goos, M. and Manning, A. 2009. Job polarisation in Europe. The American Economic Review, 99 (2), 58-63.

Green, A., Sissons, P., Ray, K., Hughes, C. and Ferreira, J. 2016, Improving progression from low-paid jobs at city-region level, York: Joseph Rowntree Foundation.

Green, A, 2012, Government policy and women in the labour market: The importance of public sector employment, Local Economy, 27, 804-815.

Grimshaw, D. (2011) What do we know about low wage work and low wage workers? Analysing the definitions, patterns, causes and consequences in international perspective. Geneva: International Labour Organization.

Hall, P. and Soskice, D. 2001. An introduction to varieties of capitalism. In Hall, P. and Soskice, D. (eds.) Varieties of Capitalism: The Institutional Foundations of Comparative Advantage. Oxford, Oxford University Press, 1-68.

Hay, C. 2013. Treating the Symptom Not the Condition: Crisis Definition, Deficit Reduction and the Search for a New British Growth Model. The British Journal of Politics and International Relations. 15 (1), 23-37.

Holmes, C. \& Mayhew, K, 2010, Are UK Labour Markets Polarising?, SKOPE Research Paper, 97.

Hurrell, A, 2013, Starting out or getting stuck? An analysis of who gets trapped in low paid work - and who escapes, London: Resolution Foundation.

HM Government, 2017, Building our industrial strategy - Green paper. London HMSO.

Joseph Rowntree Foundation, 2014. Monitoring poverty and social exclusion 2014. York: Joseph Rowntree Foundation. 
Jenkins, S. 2011. Changing fortunes: income mobility and poverty dynamics in Britain.

Oxford, Oxford University Press.

Joseph Rowntree Foundation, 2017, Response to the industrial strategy Green Paper, York: JRF.

Jones, P, S, and Green, A, E, 2009, The quantity and quality of jobs: changes in UK regions, 1997 - 2007, Environment and Planning A, 41, 10, 2474-2495.

Keep, E. (2016) 'Improving Skills Utilisation in the UK - Some Reflections on What, Who and How?'. SKOPE Research Paper No. 123, August 2016

Kemp, P., Bradshaw, J., Dornan, P, Finch, N. and Mayhew, E, 2004, Routes out of poverty: A research review, York: Joseph Rowntree Foundation.

Lee, N. 2014. Grim down South? The Determinants of Unemployment Increases in British Cities in the 2008-2009 Recession. Regional Studies, 48 (11), 1761-1778.

Leitch, S. 2006, Prosperity for All in the Global Economy - World Class Skills: Final Report. London, HM Treasury.

Lewis, P. 2011, Upskilling the workers will not upskill the work. Why the dominant economic framework limits child poverty reduction in the UK, Journal of Social Policy, 40, $535-556$.

Lindsay, C \& McQuaid, R 2004, Avoiding the 'McJobs': unemployed job seekers and attitudes to service work, Work, Employment and Society, 18, (2), 297-319

Linneker, B. and Wills, J., 2016, The London living wage and in-work poverty reduction: Impacts on employers and workers, Environment and Planning C: Government and Policy, $34,5,759-776$.

Machin, S (2015) Real Wage Trends. Available at https://www.ifs.org.uk/uploads/Presentations/Understanding\%20the\%20recession_230915/S Machin.pdf

Maitre B., Nolan, B. and Whelan, C, 2012, Low Pay, in-work poverty and economic vulnerability: A comparative analysis using EU-SILC, The Manchester School, 80, 1, 99-116.

Marx, I., Vanhille, J. and Verbist, G, 2012, Combating in-work poverty in continental Europe: An investigation using the Belgian case, Journal of Social Policy, 41, 1, 19-41.

McKnight, A, 2015, The Coalition's Record on Employment: Policy, Spending and Outcomes 2010-2015. CASE Working Paper, LSE.

Montgomery, T., Mazzei, M., Baglioni, S., Sinclair, S. 2017, Who cares? The social care sector and the future of youth employment. Policy \& Politics, DOI:

$10.1332 / 030557316$ X14778312165186

North, D., Syrett, S., and Etherington, D, 2009, Tackling concentrated worklessness: integrating governance and policy across and within spatial scales, Environment and Planning C: Government and Policy, 27, 1022-1039. 
ONS, 2015. What is the productivity puzzle? Office of National Statistics, Newport.

Payne, J, 2007, Sector skills councils and employer engagement -delivering the 'employer-led' skills agenda in England, SKOPE Research Paper 78, Cardiff University.

Riley, R. and Rosazza Bondibene, C. 2017, Raising the standard: Minimum wages and firm productivity. Labour Economics, 44, 27-50.

Rubery, J, Keizer, A, and Grimshaw, D, 2016, Flexibility bites back: the multiple and hidden costs of flexible employment policies, Human Resource Management Journal, 26, 3, 235 251.

Scott, G, 2006, Active labour market policy and the reduction of policy in the 'new' Scotland, Critical Social Policy, 26, 3, 669-684.

Shildrick, T, McDonald, R, Webster, C. and Garthwaite, K. 2014, Poverty and Insecurity: Life in low-pay, no-pay Britain, Bristol: Policy Press/

Sissons, P, 2011, The Hourglass and the Escalator: Labour market change and mobility, London: The Work Foundation.

Sissons, P. and Green, A. (in press) More than a match? Assessing the HRM challenge of engaging employers to support retention and progression, Human Resource Management Journal. DOI: $10.1111 / 1748-8583.12161$

Sissons, P., Green, A. and Lee, N. 2016. Supporting progression in growth sectors. Public Policy Institute for Wales, Cardiff.

Sissons, P., Green, A. and Lee, N. 2017. Improving job quality in growth sectors. Public Policy Institute for Wales, Cardiff.

Standing, G. 2011, The Precariat: The new dangerous class, London, Bloomsbury.

Stewart, K. 2009, Employment and wage trajectories for mothers entering low-skilled work: Evidence from the British lone parent cohort, Social Policy \& Administration, 43, 5, 483-507.

Stewart, K, 2013, Employment Trajectories and Later Employment Outcomes for Mothers in the British Household Panel Survey: An Analysis by Skill Level, Journal of Social Policy, 43 $1,87-108$.

Solow, R, 2008, The United Kingdom Story, in Lloyd, C., Mason, C. and Mayhew, K. eds., Low-wage work in the United Kingdom, New York: Russell Sage, 1-14.

Taylor, R. \& Rees, J. 2016, UK employment services: understanding provider strategies in a dynamic strategic action field, Policy \& Politics, 44 (2), 253-67

Tilly, G. 2017, UK $3^{\text {rd }}$ out of 112 in global ranking for real wage growth since the crisis. TUC Touchstone Blog, $27^{\text {th }}$ February 2017. Available from: http://touchstoneblog.org.uk/2017/02/uk-103rd-112-global-ranking-real-wage-growth-sincecrisis/ [Accessed 24 ${ }^{\text {th }}$ April 2017] 
Thompson, S., Colebrook, C., Hatfield, I. and Doyle, P., 2016, Boosting Britain's low-wage sectors: A strategy for productivity, innovation and growth. London: Institute for Public Policy Research.

Ton, Z, 2014, The Good Jobs Strategy, New York: Houghton Mifflin Harcourt.

Ward, R., Woods, J. and Haigh, R., 2016, Sector-based Work Academies: a quantitative impact assessment, DWP Research Report 918. DWP.

https://www.gov.uk/government/uploads/system/uploads/attachment_data/file/508175/rr918sector-based-work-academies.pdf

Wills, J. \& Linneker, B., 2014, In-work poverty and the living wage in the United Kingdom: a geographical perspective, Transactions of the Institute of British Geographers, 39, 2, 182194.

Wilson, R. and Hogarth, T. (2003) Tackling the Low Skills Equilibrium. London: Department for Trade and Industry.

Wilson, R., Sofroniou, N., Beaven, R., May-Gillings, M., Perkins, S. and Lee, M., 2016, Working Futures 2014-2024, Evidence Report 100, Wath-upon-Dearne: UK Commission for Employment and Skills.

Wilson, S. (2017) 'The Politics of 'Minimum Wage' Welfare States: The Changing Significance of the Minimum Wage in the Liberal Welfare Regime'. Social Policy \& Administration, 51: 244-264. doi: 10.1111/spol.12286

Wolf, A. 2011, Review of Vocational Education -The Wolf Report. London: HMSO.

Wright, S. (2016) Conceptualising the active welfare subject: welfare reform in discourse, policy and lived experience. Policy and Politics, 44(2), pp. 235-252. 
Table 1. Share of workers in low pay by year, UK 2010-2014

$\begin{array}{llllll}\text { Year } & 2010 & 2011 & 2012 & 2013 & 2014\end{array}$

$\begin{array}{llllll}\text { \% of workers in low pay } & 21.1 & 20.6 & 20.9 & 20.4 & 21.1\end{array}$

Source: LFS. Low pay defined as $<60 \%$ of average hourly pay. 
Table 2. Percentage of workers in low pay by sector, UK 2010-2014

\begin{tabular}{ll} 
Sector & Low pay \\
\hline & \\
Agriculture & 35.4 \\
Mining & 4.5 \\
Manufacturing & 14.8 \\
Electricity, gas, air conditioning, and water supply & 4.0 \\
Water supply, sewerage and waste & 11.5 \\
Construction & 12.9 \\
Wholesale, retail & 39.1 \\
Transport and communications & 14.4 \\
Accommodation & 59.1 \\
Information and & 7.2 \\
Financial and insurance activities & 5.0 \\
Real estate activities & 10.9 \\
Professional, scientific and technical activities & 8.6 \\
Admin and support services & 29.7 \\
Public administration and defence & 3.8 \\
Education & 16.6 \\
Arts, entertainment and recreation & 29.2 \\
Other service activities & 34.0 \\
Human Health & 8.2 \\
Residential care & 40.0 \\
Social work & 19.5 \\
\hline Total & \\
\hline Observations & 20.8
\end{tabular}

Observations: 132,921 
Table 3. Percentage of those in low pay by sector, UK 2010-2014

Sector $\%$ of total

$\%$ of low paid

employment

employment

$\begin{array}{lll}\text { Agriculture } & 0.6 & 1.0\end{array}$

Mining

0.4

1.0

Manufacturing

10.7

7.7

Electricity, gas, air conditioning, and water

0.6

7.7

supply

Water supply, sewerage and waste

0.1

Construction

0.8

0.5

Wholesale and retail

5.2

14.5

3.3

Transport and communications

4.8

27.4

Accommodation and food services

5.7

3.3

Information and communications

3.7

15.8

Financial and insurance

4.4

1.3

Real estate activities

1.0

1.1

Professional, scientific and technical activities

5.7

0.5

Admin and support services

4.4

2.3

Public administration and defence

7.2

6.2

Education

11.3

1.3

Arts, entertainment and recreation

2.2

9.0

Other service activities

2.2

3.1

Human Health

7.8

3.3

Residential care

3.4

3.1

Social work

3.3

6.3

3.2

\begin{tabular}{lll}
\hline Total & 100.00 & 100.00
\end{tabular}

Source: LFS. Obs: 132,921 
Table 4. Share of low paid in Q1 leaving by Q5, UK 2010 - 2014

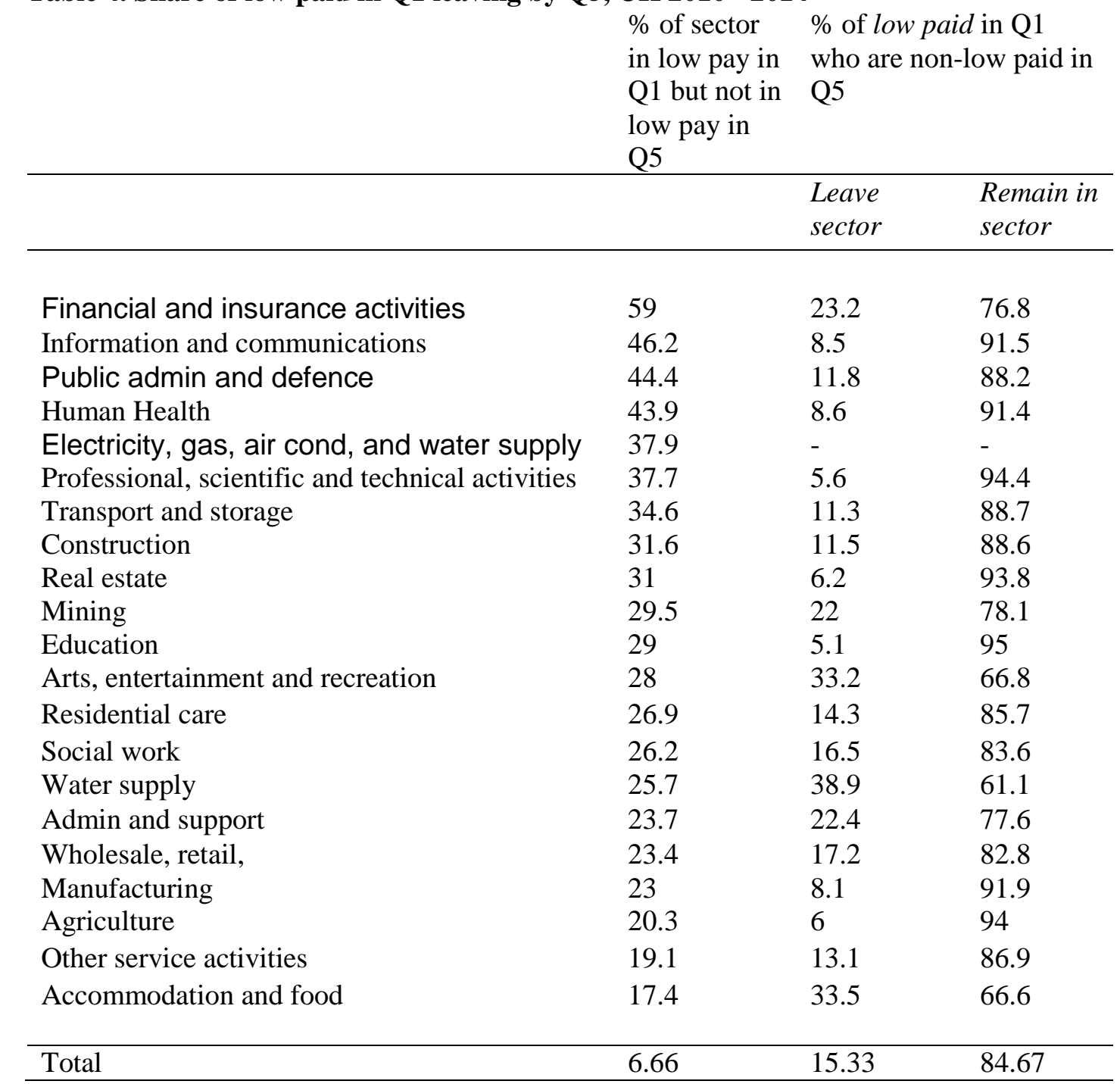

Source: LFS. Obs: 59,568. Figures suppressed for Electricity and Gas due to small sample size. 
Table 5. Probit regressions: probability of low pay, UK 2010-2014

\begin{tabular}{|c|c|c|c|c|c|c|}
\hline \multirow{3}{*}{$\begin{array}{l}\text { Dependent variable: } \\
\text { Estimation method }\end{array}$} & \multirow{2}{*}{\multicolumn{3}{|c|}{ Low pay $\left(<2 / 3^{\text {rd }}\right.$ Median wage $)$}} & \multirow{2}{*}{\multicolumn{3}{|c|}{$\begin{array}{l}\text { (4) } \\
\text { Low pay in Q1 to non-low pay in Q5 } \\
\text { (Any sector) }\end{array}$}} \\
\hline & & & & & & \\
\hline & Probit & Probit & $\begin{array}{l}\text { Probit with } \\
\text { selection equation } \\
\text { for employment }\end{array}$ & Probit & Probit & $\begin{array}{l}\text { Probit with } \\
\text { selection equation } \\
\text { for employment }\end{array}$ \\
\hline A Agriculture, forestry and fishing & $\begin{array}{l}0.221 * * * \\
(0.0202)\end{array}$ & $\begin{array}{l}0.163 * * * \\
(0.0199)\end{array}$ & $\begin{array}{l}-0.0301 \\
(0.0383)\end{array}$ & $\begin{array}{l}-0.00648 \\
(0.00637)\end{array}$ & $\begin{array}{l}-0.00639 \\
(0.00579)\end{array}$ & $\begin{array}{l}-0.0274 \\
(0.0452)\end{array}$ \\
\hline B Mining and quarrying & $\begin{array}{l}-0.121 * * * \\
(0.0124)\end{array}$ & $\begin{array}{l}-0.0845^{* * *} \\
(0.0131)\end{array}$ & $\begin{array}{l}-0.523 * * * \\
(0.0930)\end{array}$ & $\begin{array}{l}-0.0121 \\
(0.0101)\end{array}$ & $\begin{array}{l}-0.00731 \\
(0.0109)\end{array}$ & $\begin{array}{l}0.0390 \\
(0.126)\end{array}$ \\
\hline D Electricity, gas, air cond, \& water supply & $\begin{array}{l}-0.127 * * * \\
(0.00928)\end{array}$ & $\begin{array}{l}-0.0984 * * * \\
(0.00935)\end{array}$ & $\begin{array}{l}-0.605 * * * \\
(0.0790)\end{array}$ & $\begin{array}{l}-0.00772 \\
(0.00833)\end{array}$ & $\begin{array}{l}-0.00501 \\
(0.00831)\end{array}$ & $\begin{array}{l}0.119 \\
(0.120)\end{array}$ \\
\hline E Water supply, sewerage, waste & $\begin{array}{l}-0.0373 * * * * \\
(0.0126)\end{array}$ & $\begin{array}{l}-0.0350 * * * * \\
(0.0111)\end{array}$ & $\begin{array}{l}-0.144 * * * \\
(0.0511)\end{array}$ & $\begin{array}{l}-0.00741 \\
(0.00793)\end{array}$ & $\begin{array}{l}-0.00612 \\
(0.00744)\end{array}$ & $\begin{array}{l}-0.0149 \\
(0.0601)\end{array}$ \\
\hline F Construction & $\begin{array}{l}-0.0223 * * * \\
(0.00633)\end{array}$ & $\begin{array}{l}-0.0164 * * * * \\
(0.00596)\end{array}$ & $\begin{array}{l}-0.331 * * * \\
(0.0218)\end{array}$ & $\begin{array}{l}-0.00998 * * * \\
(0.00317)\end{array}$ & $\begin{array}{l}-0.00959 * * * \\
(0.00288)\end{array}$ & $\begin{array}{l}0.0221 \\
(0.0312)\end{array}$ \\
\hline G Wholesale, retail, repair of vehicles & $\begin{array}{l}0.244 * * * \\
(0.00621)\end{array}$ & $\begin{array}{l}0.120^{* * * *} \\
(0.00571)\end{array}$ & $\begin{array}{l}0.381 * * * \\
(0.0158)\end{array}$ & $\begin{array}{l}0.0462 * * * \\
(0.00526)\end{array}$ & $\begin{array}{l}0.0235 * * * * \\
(0.00412)\end{array}$ & $\begin{array}{l}0.0419 * * \\
(0.0199)\end{array}$ \\
\hline H Transport and storage & $\begin{array}{l}-0.00441 \\
(0.00644)\end{array}$ & $\begin{array}{l}-0.00959 \\
(0.00587)\end{array}$ & $\begin{array}{l}-0.0796 * * * \\
(0.0218)\end{array}$ & $\begin{array}{l}0.0125^{* *} \\
(0.00507)\end{array}$ & $\begin{array}{l}0.00934 * * \\
(0.00455)\end{array}$ & $\begin{array}{l}0.0930 * * \\
(0.0369)\end{array}$ \\
\hline I Accommodation and food services & $\begin{array}{l}0.450 * * * \\
(0.00828)\end{array}$ & $\begin{array}{l}0.254 * * * \\
(0.00920)\end{array}$ & $\begin{array}{l}0.569 * * * \\
(0.0195)\end{array}$ & $\begin{array}{l}0.0509 * * * \\
(0.00803)\end{array}$ & $\begin{array}{l}0.0184 * * * * \\
(0.00551)\end{array}$ & $\begin{array}{l}0.00459 \\
(0.0276)\end{array}$ \\
\hline $\mathrm{J}$ Information and communication & $\begin{array}{l}-0.0893^{* * * *} \\
(0.00564)\end{array}$ & $\begin{array}{l}-0.0432 * * * * \\
(0.00661)\end{array}$ & $\begin{array}{l}-0.274 * * * \\
(0.0302)\end{array}$ & $\begin{array}{l}-0.00813^{* *} \\
(0.00409)\end{array}$ & $\begin{array}{l}-0.00331 \\
(0.00435)\end{array}$ & $\begin{array}{l}0.0876 \\
(0.0559)\end{array}$ \\
\hline K Financial and insurance activities & $\begin{array}{l}-0.118 * * * \\
(0.00456)\end{array}$ & $\begin{array}{l}-0.0952 * * * \\
(0.00447)\end{array}$ & $\begin{array}{l}-0.556^{* * * *} \\
(0.0314)\end{array}$ & $\begin{array}{l}-0.00405 \\
(0.00434)\end{array}$ & $\begin{array}{l}-0.00588 \\
(0.00372)\end{array}$ & $\begin{array}{l}0.183 * * \\
(0.0834)\end{array}$ \\
\hline L Real estate activities & $\begin{array}{l}-0.0453^{* * * *} \\
(0.0112)\end{array}$ & $\begin{array}{l}-0.0486 * * * \\
(0.00967)\end{array}$ & $\begin{array}{l}-0.276 * * * \\
(0.0450)\end{array}$ & $\begin{array}{l}-0.00564 \\
(0.00768)\end{array}$ & $\begin{array}{l}-0.00798 \\
(0.00630)\end{array}$ & $\begin{array}{l}0.0158 \\
(0.0640)\end{array}$ \\
\hline M Prof, scientific, technical activ. & $\begin{array}{l}-0.0732^{* * * *} \\
(0.00509)\end{array}$ & $\begin{array}{l}-0.0300 * * * \\
(0.00581)\end{array}$ & $\begin{array}{l}-0.265 * * * \\
(0.0237)\end{array}$ & $\begin{array}{l}-0.00623^{*} \\
(0.00346)\end{array}$ & $\begin{array}{l}-0.00404 \\
(0.00339)\end{array}$ & $\begin{array}{l}0.0517 \\
(0.0370)\end{array}$ \\
\hline N Admin and support services & $\begin{array}{l}0.160^{* * *} \\
(0.00852)\end{array}$ & $\begin{array}{l}0.102 * * * \\
(0.00801)\end{array}$ & $\begin{array}{l}0.193 * * * \\
(0.0204)\end{array}$ & $\begin{array}{l}0.0265 * * * \\
(0.00621)\end{array}$ & $\begin{array}{l}0.0151 * * * \\
(0.00510)\end{array}$ & $\begin{array}{l}0.0457^{*} \\
(0.0256)\end{array}$ \\
\hline O Public admin and defence & $\begin{array}{l}-0.137 * * * \\
(0.00341)\end{array}$ & $\begin{array}{l}-0.110 * * * \\
(0.00328)\end{array}$ & $\begin{array}{l}-0.585^{* * *} \\
(0.0267)\end{array}$ & $\begin{array}{l}-0.00883^{* * *} \\
(0.00315)\end{array}$ & $\begin{array}{l}-0.00909 * * * \\
(0.00281)\end{array}$ & $\begin{array}{l}0.106^{*} \\
(0.0591)\end{array}$ \\
\hline P Education & $\begin{array}{l}0.0197 * * * \\
(0.00508)\end{array}$ & $\begin{array}{l}0.0320 * * * \\
(0.00528)\end{array}$ & $\begin{array}{l}0.113 * * * \\
(0.0178)\end{array}$ & $\begin{array}{l}0.0208 * * * \\
(0.00417)\end{array}$ & $\begin{array}{l}0.0143 * * * \\
(0.00380)\end{array}$ & $\begin{array}{l}0.0545 * * \\
(0.0224)\end{array}$ \\
\hline $\mathrm{R}$ Arts, entertainment and recreation & $\begin{array}{l}0.155 * * * \\
(0.0110)\end{array}$ & $\begin{array}{l}0.0626 * * * \\
(0.00946)\end{array}$ & $\begin{array}{l}0.0527 * * \\
(0.0264)\end{array}$ & $\begin{array}{l}0.0233^{* * * *} \\
(0.00754)\end{array}$ & $\begin{array}{l}0.0102^{*} \\
(0.00582)\end{array}$ & $\begin{array}{l}0.0738^{* *} \\
(0.0356)\end{array}$ \\
\hline S Other service activities & $0.187 * * *$ & $0.116^{* * * *}$ & 0.0394 & 0.00923 & 0.00136 & -0.00188 \\
\hline Human health & $\begin{array}{l}(0.0110) \\
-0.0786^{* * *}\end{array}$ & $\begin{array}{l}(0.0103) \\
-0.0755^{* * *}\end{array}$ & $\begin{array}{l}(0.0243) \\
-0.355^{* * *}\end{array}$ & $\begin{array}{l}(0.00595) \\
0.00551\end{array}$ & $\begin{array}{l}(0.00481) \\
0.000644\end{array}$ & $\begin{array}{l}(0.0297) \\
0.185 * * *\end{array}$ \\
\hline
\end{tabular}




\begin{tabular}{|c|c|c|c|c|c|c|}
\hline & $(0.00441)$ & $(0.00396)$ & $(0.0218)$ & $(0.00396)$ & $(0.00347)$ & $(0.0472)$ \\
\hline \multirow{2}{*}{ Residential care } & $0.265^{* * *}$ & $0.178 * * *$ & $0.546 * * *$ & $0.0707 * * *$ & $0.0444 * * *$ & 0.0250 \\
\hline & $(0.00949)$ & $(0.00958)$ & $(0.0225)$ & $(0.0101)$ & $(0.00821)$ & $(0.0247)$ \\
\hline \multirow[t]{2}{*}{ Social work } & 0.0510 **** & $0.0211 * * *$ & -0.00683 & $0.0202 * * *$ & $0.00928^{*}$ & $0.0531^{*}$ \\
\hline & $(0.00801)$ & $(0.00724)$ & $(0.0241)$ & $(0.00613)$ & $(0.00496)$ & $(0.0313)$ \\
\hline \multirow[t]{2}{*}{ Disabled } & & $0.0457 * * *$ & $0.304 * * *$ & & 0.000285 & \\
\hline & & $(0.00544)$ & $(0.0355)$ & & $(0.00231)$ & \\
\hline \multirow{2}{*}{ UK Born } & & $-0.0411 * * *$ & $-0.163 * * *$ & & $0.0223 * * *$ & -0.0405 \\
\hline & & $(0.00540)$ & $(0.0156)$ & & $(0.00216)$ & $(0.0325)$ \\
\hline \multirow[t]{2}{*}{ Education (Low) } & & $0.259 * * *$ & $0.825 * * *$ & & $0.0201 * * *$ & -0.0163 \\
\hline & & $(0.00537)$ & $(0.0188)$ & & $(0.00223)$ & $(0.0230)$ \\
\hline \multirow[t]{2}{*}{ Education (medium) } & & $0.118^{* * * *}$ & $0.496 * * *$ & & $-0.00197 * * *$ & 0.00531 \\
\hline & & $(0.00289)$ & $(0.0106)$ & & $(0.000340)$ & $(0.00416)$ \\
\hline \multirow[t]{2}{*}{ Age } & & $-0.0305 * * *$ & $-0.122 * * *$ & & $1.78 \mathrm{e}-05 * * *$ & $-6.96 \mathrm{e}-05$ \\
\hline & & $(0.000602)$ & $(0.00608)$ & & $(4.08 \mathrm{e}-06)$ & $(4.74 \mathrm{e}-05)$ \\
\hline \multirow[t]{2}{*}{$\mathrm{Age}^{2}$} & & $0.000322 * * *$ & $0.00128^{* * * *}$ & & -0.00137 & $-0.0474 * *$ \\
\hline & & $(7.31 \mathrm{e}-06)$ & $(7.50 \mathrm{e}-05)$ & & $(0.00413)$ & $(0.0238)$ \\
\hline \multirow[t]{2}{*}{ Non-white } & & $0.0667 * * *$ & $0.179 * * *$ & & $-0.00945 * * *$ & 0.00904 \\
\hline & & $(0.00548)$ & $(0.0188)$ & & $(0.00159)$ & $(0.0129)$ \\
\hline \multirow[t]{2}{*}{ Male } & & $-0.0506^{* * * *}$ & $-0.0832^{* * * *}$ & & $0.0161 * * *$ & -0.00941 \\
\hline & & $(0.00257)$ & $(0.00555)$ & & $(0.00186)$ & $(0.0178)$ \\
\hline \multirow[t]{2}{*}{ Part-time } & & $0.142 * * *$ & $0.107 * * *$ & & & \\
\hline & & $(0.00328)$ & $(0.00342)$ & & & \\
\hline Observations & 129,250 & 127,987 & 273,528 & 59,568 & 58,845 & 44,577 \\
\hline Pseudo R2 & 0.131 & 0.260 & & 0.0320 & 0.0638 & \\
\hline Year / quarter dummies & Yes & Yes & Yes & & & \\
\hline Region dummies & No & Yes & Yes & & & \\
\hline Observations & 129,250 & 127,945 & 273,019 & & & \\
\hline Pseudo R2 & 0.1317 & 0.2606 & & & & \\
\hline \multirow[t]{2}{*}{ LR Test } & & & 31.44 & & & 3.82 \\
\hline & & & 0.0000 & & & 0.0507 \\
\hline \multirow[t]{2}{*}{ Wald $\mathrm{Chi}^{2}$-value } & & & 26756.40 & & & 175.27 \\
\hline & & & 0.0000 & & & 0.0000 \\
\hline
\end{tabular}

Marginal effects presented. Standard errors in parentheses. *** $\mathrm{p}<0.01, * * \mathrm{p}<0.05, * \mathrm{p}<0.1$ 
Figure 1. Share of workers in low pay versus chances of upward wage mobility in the UK, 2010-14

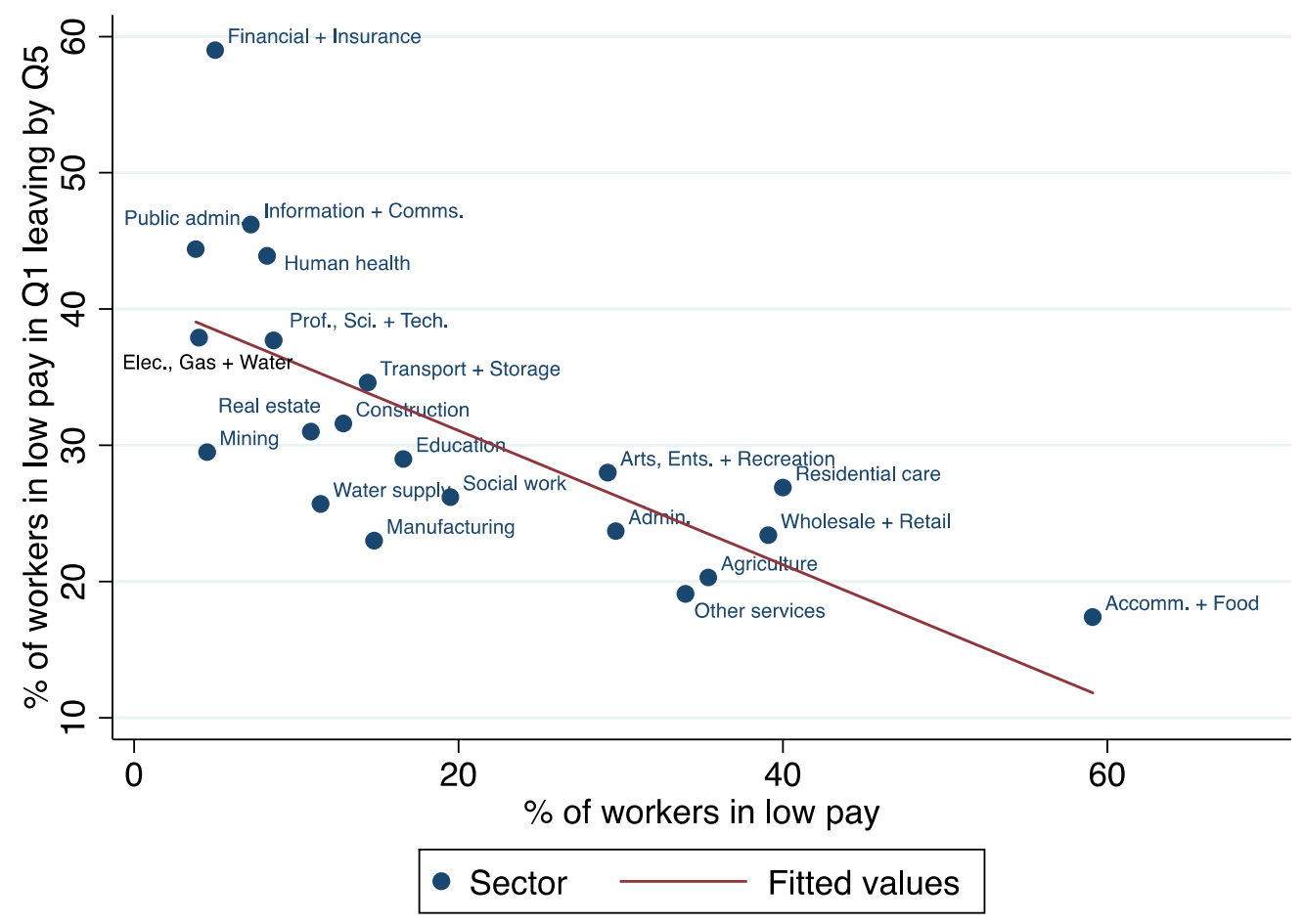


Figure 2. Marginal effects of low pay by sector, controlling for personal characteristics, UK 2010-14

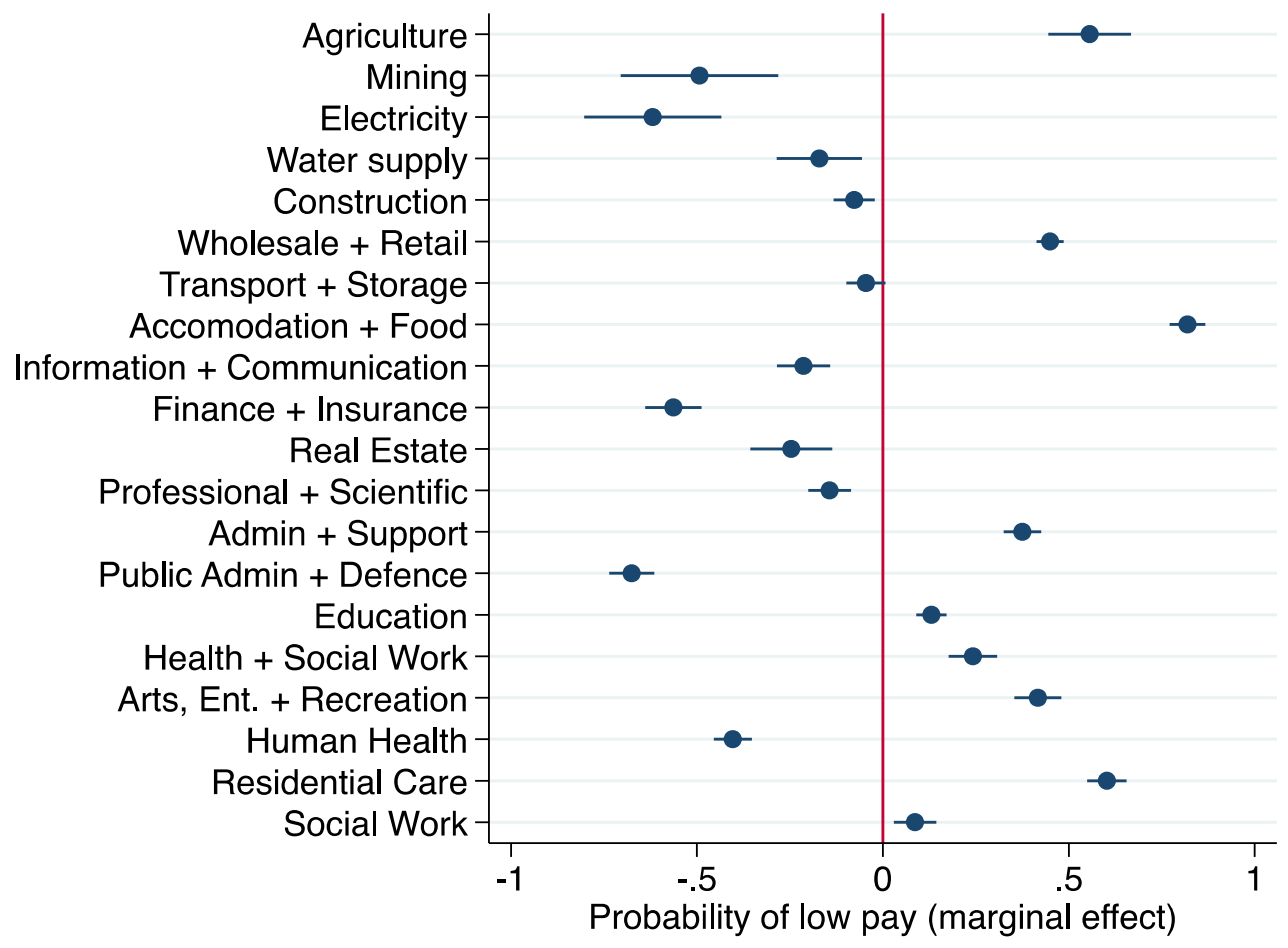

Source: LFS. Dots indicate the marginal effect for each sectoral variable of the regression presented in table 5, column 2. Lines give 95\% confidence intervals, with red bar indicating zero. Reference category = Manufacturing. Controls: education, age, age2, country of birth, region, and year/quarter fixed effects. 
Figure 3. Low pay and projected employment growth, 2014-2024

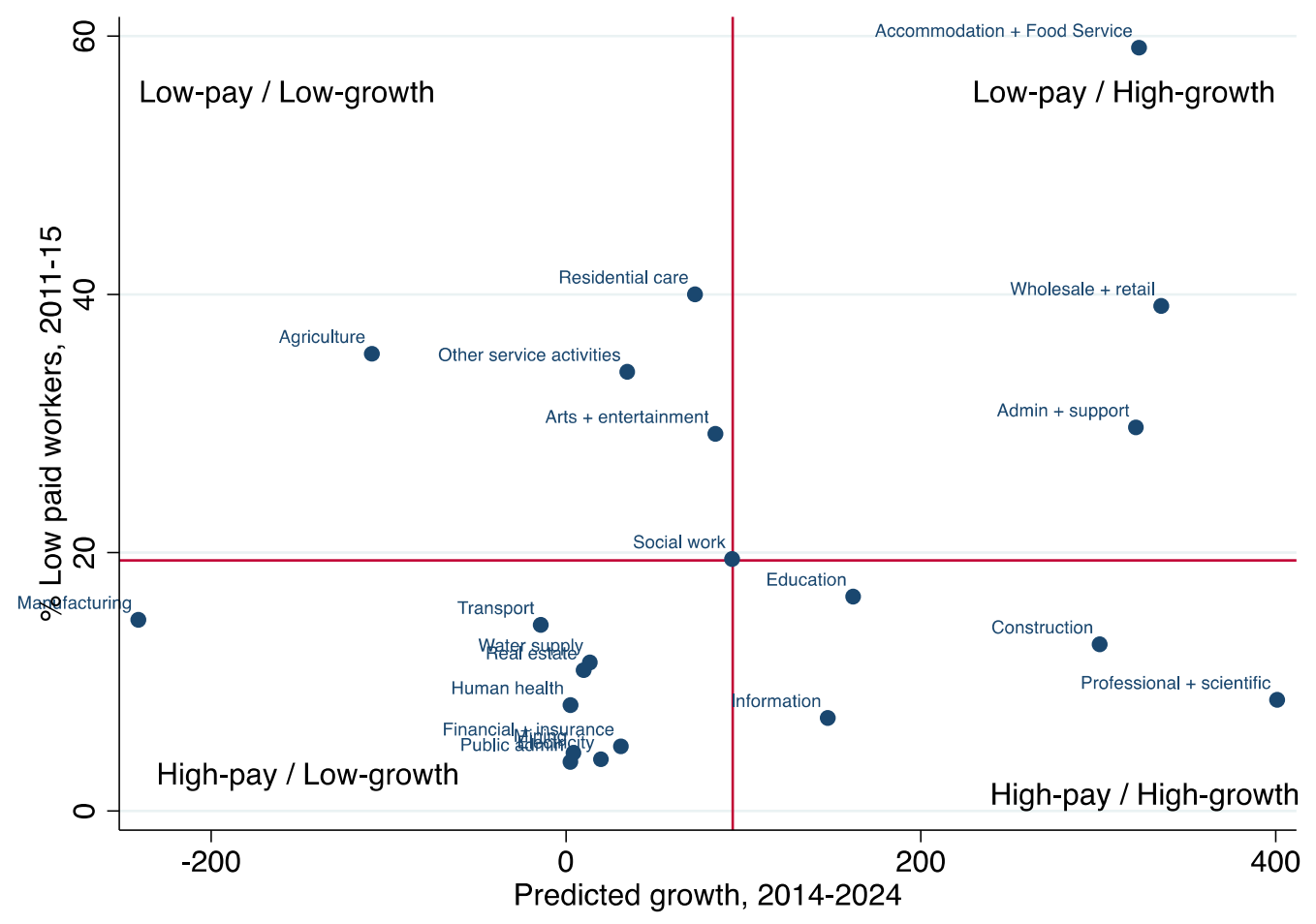

Source: LFS + Working Futures 2016. 